\title{
Cultural Influences on Leadership: Western-Dominated Leadership and Non-Western Conceptualizations of Leadership
}

\author{
Nhung-Binh Ly \\ Faculty of Education, University of Social Sciences and Humanities (USSH), Vietnam National University, Ho Chi Minh City, Vietnam
}

Received October 7, 2019; Revised December 10, 2019; Accepted December 17, 2019

Copyright $\bigcirc 2020$ by authors, all rights reserved. Authors agree that this article remains permanently open access under the terms of the Creative Commons Attribution License 4.0 International License

\begin{abstract}
While the phenomenon of leadership is widely considered to be universal across cultures, how it is operationalized is usually viewed as culturally specific. Conflicting viewpoints exist in the leadership literature concerning the transferability of specific leader behaviors and processes across cultures. This study explored commonalities and differences in effective leadership processes, across - cultures in western - dominated leadership and non-western conceptualization of leadership. GLOBE (Global Leadership and Organizational Behavior Effectiveness) is a research program focusing on culture and leadership in 61 nations to provide core attributes of cultural dimensions on cross-culture and evidence for conceptual and measurement equivalence for all six leader behaviors in viewpoints of globalization. Data for the study is drawn principally from analytic literature reviews in leadership theory and its implication on cross-culture perspectives.
\end{abstract}

Keywords Leadership, Western Perspective of Leadership, Non-Western Conceptualization of Leadership, Cultural Influences on Leadership

Arabs worship their leaders - as long as they are in power!

-House, Wright, and Aditya (1997, p. 535)

The Malaysian leader is expected to behave in a manner that is humble, modest and dignified.

- House et al. (1997, p. 535)

The Americans appreciate two kinds of leaders. They seek empowerment from leaders who grant autonomy and delegate authority to subordinates. They also respect the bold, forceful, confident, and risk-taking leader as personified by John Wayne.

- House et al. (1997, p. 536)
For Europeans ... everything seems to indicate that leadership is an unintended and undesirable consequence of democracy.

-Graumann and Moscovici (1986, pp. 241-242)

Indians prefer leaders who are nurturant, caring, dependable, sacrificing and yet demanding, authoritative, and strict disciplinarian.

—Sinha (1995, p. 99)

\section{Introduction}

As stated in the above quotations, leadership, as seen through the eyes of followers, cannot be studied without taking into account the effect of cultural context. To remain key players in the global development, organizations invest in developing leaders who have competencies to understand and manage diversity both at home and globally (Bartlett \& Ghoshal, 1998; Bartlett, Ghoshal, \& Birkinshaw, 2004; Peterson \& Hunt, 1997). Today's international organizations require leaders who can adjust to different environments quickly and work with partners and employees of other cultures (House, Javidan, and Dorfman, 2001). It cannot be assumed that a manager who is successful in one country will be successful in another. Cross-cultural leadership helps organizations understand the cultural contingencies under which certain leadership approaches work better than others. Increasingly, leaders are coming to see their role in change as a task of creating a harmonious culture to undergird both personal and institutional growth. Once leaders have created and generalized unifying cultural background, they can allow co-workers to change the organizational structure or system because they share common aims. The trust culture provides a unifying context within which leader and follower work and focuses effort toward agreed-upon goals, 
values, and vision ideals (Gilbert, 1994). Before embarking on a discussion of models for global leadership development, this study firstly provides a cross-culture in Western leadership theories and Non-Western theories of leadership to explore commonalities and differences in effective leadership processes, and finally, present the features of leadership portrayed in viewpoints of globalization.

\section{Leadership from Western Perspective}

The word leadership is a relatively new addition to the English language; it appeared approximately 200 years ago in writings about political influence in the British Parliament. However, from Egyptian hieroglyphics, symbols for "leader" existed as long as 5.000 years ago (Dorfman, 1996). The concept of leadership has existed in all cultures throughout history. Descriptions of great leaders are present in such culturally diverse writings as Homer's Iliad, the Bible, and Confucius. Despite the thousands of research have been written on the subject, no generally accepted definition of leadership exists (Bass, 1990). Western definitions tend to focus on the ability of individuals to influence organization members toward the accomplishment of goals (Yukl, 1994b). Janda (1972) and Bums (1978) insist that an understanding of "the nature of leadership requires the understanding of the essence of power, for leadership is a special form of power". Power in its various forms (coercive, legitimate, reward and expert, bureaucratic and charismatic power) is present to some degree in any leader-follower relationship (French \& Raven, 1959). However, based on the well-established idea that systematic variations in values, attitudes, beliefs, and behavior exist across cultures, it seems likely that the meaning and importance of leadership also varies across cultures. To examine the possible nature of this variation, it is valuable to review briefly the development of leadership theory.

Western leadership theory is often described as having progressed through six distinct periods. These are the trait, behavioral, situational, transformational, visionary and charismatic theories.

According to traditional trait theories, certain individuals possess innate qualities that enable them to lead (Northouse, 2010). In traditional trait approach, leaders are born, leaders born with some characteristics due to their psychological personality (Gill (2006) Northouse (2010) identifies intelligence, self-confidence, determination, integrity, and sociability as the five traditional traits associated with effective leadership and that it is these traits that distinguish leaders from followers. There is evidence to suggest that some of the traits thought to be important to leadership are culturally determined. According to Tannebaum (1980), authoritarianism and dominance seem to be more acceptable in some developing countries. In New Zealand, effective Polynesian leaders tend to emphasize discipline and conformity, while Anglo-European leader relies less on formal authority (Marsh, 1978). However, for Americans, traits of intelligence, honesty, understanding, verbal skills and determination are strongly affirmed as facilitating leader effectiveness (Yukl, 2002). Robbins and Jude (2009) point out "The Big Five personality traits", Maxwell (1999) describes "21 indispensable qualities of a leader", Collins (2001) raises out the concept of "Level-5 Leadership" which emphasize leaders to transmit their ego into the goal of building a great organization based on the four basic leadership qualities (individual capability, team skills, managerial competence, and ability to simulate other to high performance) in $21^{\text {st }}$ century (See The Appendix-1 for the list).

Scholars in the behavioral school, House and Mitchell (1974) identify directive, supportive, participative and achievement-oriented leadership behaviors that are often categorized as leadership styles. From this perspective, scholars identified person-oriented, task-oriented and individual prominence behaviors as related to leadership effectiveness. Northouse (2010) points out three main categories: task, relation and change behavior which are important for leadership effectiveness. According to Northouse (2010), task-oriented behavior promotes goal accomplishment and help group members to achieve their objectives. Relationship-oriented behavior helps subordinates feel comfortable with themselves, with each other and with the situation in which they find themselves. Change-oriented behavior is concerned with understanding the environment, finding innovative ways to adapt to it, and implementing major changes in strategies, products, or processes. The table in The Appendix - 2 provides a summary of specific leader behaviors to be represented in a task-oriented, relationship-oriented, change-oriented leadership style.

The situational approach emphasizes contextual factors influencing leadership processes. The basic argument of this approach is that different situations warrant different kinds of leadership. Leadership effectiveness is enhanced only when leaders pick up cues in the environment and adapt their policies, behaviors, and actions accordingly. The leaders must adjust their leadership style (delegative, supportive, directive, coaching) to match the varying level of religious, personal and psychological maturity of their followers. To be able to shape events, the leaders must recognize the situation and the needs of the employees. This gives rise to considerations about factors that help a leader transform the behavior of followers (Northouse, 2004). According to Greer (2013), the effective leaders in $21^{\text {st }}$-century must understand behavioral, economic and social shifts and should be flexible and follow the most appropriate leadership style to the situation. Situational models reinforce leadership development and movement to 
exploit opportunities and achieve success.

Transformational theories focus on how leaders motivate followers to pursue goals that transcend their immediate self- interest. Charismatic or transformational leader "shapes and shares a vision which provides direction, focus, meaning and inspiration to the work of others" (Blunt, 1991). Transformational theories mainly promote desirable attitudes, values, and beliefs which affect the culture. They attach considerable importance to such values as relative equality of power between leaders and the led, high tolerance of ambiguity, high levels of trust and openness and a desire to share feelings and emotions. They also emphasize values such as trust, teamwork, rationality, delegation, productivity and customer service, among others. Transformational leaders mobilize their followers through "idealized influence" (charisma), "inspirational motivation", intellectual stimulation, high-performance expectations and effective articulation of a vision (Bass, 1997). According to Northouse, 2004, from a transformational perspective, leadership is a shared process which results in the empowerment of the people in the organization, higher level of motivation and improved productivity. There is an interaction between leaders and followers. Leaders motivate followers through promises, praise, and rewards. In this approach, there is an exchange of one thing for another such as jobs in return for votes or subsidies for campaign contributions.

The influence process for transformational leadership involves intrinsic and inspirational motivation to increase the perception of followers that task objectives are consistent with their authentic interests and values in the self-efficacy of individual subordinates (Bono \& Judge, 2003; Charbonneau, Barling \& Kelloway, 2001). Transformational leaders inspire self-confidence onto others. Leaders with confidence in their employees can secure great accomplishments. Indeed, developing the consciousness of followers, directing them towards the organizational mission and vision, and motivating others in understanding and pledging to the vision is a key dimension of the transformational leadership style of inspirational motivation (Bass \& Avolio, 2004). According to Nikezić, etc. (2013), a strong coalition in transformational leadership supports the establishment of mutual trust and common goals to be achieved in the organization. Transformational leaders develop a vision for the organization, inspire and give a collective obligation for his followers to a vision into a goal towards which they move. The transformation management also considers essential factors of development in the organization and corporate competence to other social groups and actors in adjusting the organization due to the changes in the environment. The figure in the Appendix - 3 shows key attributes of transformational leadership to meet changes in the world.

A number of studies have shown a nearly universal relationship for charismatic leadership across cultures
(Dorfman, 1996). However, a few recent studies have suggested that culture does influence the charismatic leadership process. Echavarria and Davis (1994), Hartog et al., (1994), Koh (1990) state that while the concept of a charismatic leader might be universal, the way such a leader is described by followers can differ markedly. Other evidence views that this model of leadership may not hold for some unique cultures such as Japan (Bass, 1991 \& Howell et al., 1994). Furthermore, the effect of charismatic leadership has been found to be stronger for Americans than Mexicans (Howell \& Dorfman, 1988), it is indicating that cultural differences may influence the effectiveness of the transformational or charismatic approach.

The origin of charisma theory is from the ideas of an early sociologist named Max Weber. Charisma is a Greek word that means "divinely inspired gift," such as the ability to perform miracles or predict future events (Yukl, 2006). Weber (1947) defined charisma as being:

“... set apart from ordinary people and treated as endowed with supernatural, superhuman, or at least specifically exceptional power or qualities...regarded as of divine origin or as exemplary, and on the basis of them the individual concerned is treated as a leader" (Weber, 1947, pp. 358-359)

According to Weber (1947, Charismatic leaders influence on follower perception based not on tradition or formal authority but rather on exceptional qualities. Charismatic leadership occurs during a social crisis, when a leader emerges with a profound vision that offers a solution to the crisis and attracts followers who believe in the vision. The followers experience some successes that make the vision appear attainable, and they come to perceive the leader as superior (Yukl, 2006).

House (1977) further developed Weber's concept in charismatic personality and argued that charismatic leadership is characterized by followers' trust in the correctness of the leader's beliefs. Followers not only respect and trust the leader but they would do with a transformational one in willing obedience, and they worship the leader as a spiritual or superhuman. Several social scientists (Conger \& Kanungo, 1987, 1998; Shamir, House, \& Arthur, 1993) formulated newer versions of the theory to describe charismatic leadership in organizations. The neo-charismatic theories describe the motives and behaviors of charismatic leaders and psychological processes that explain how these leaders influence followers (Jacobsen \& House, 2001).

Conger and Kanungo (1998) describe four key characteristics: "possesing, articulating a vision, willing to take riskes to achieve the vision, exhibiting sensivity to follower needs, and demonstraing novel behavior" (Timothy, etc., 2006, pp. 204-205). Northouse (2010) points out positive and negative characteristics that are often found in charismatic leadership. Positive charismatics have a socialized power orientation. 
Charismatic leaders are able to self-motivate individuals to follow their ideology and be productive in meeting the leader's organizational goals or personal goals. Nikezic (2009) states the list of the attributes of positive charismatic leader as seen in the Appendix 4. In contrast, the negative charismatic leadership is that some leaders can use their personality characteristics to mold their followers to accomplish organizational or personal goals that are as seen in the Appendix 5. Yukl (2006) describes negative charismatics in terms of their values and personality as follows:

Negative charismatics have a personalized power orientation... They intentionally seek to instill devotion to themselves more than to ideals. They may use ideological appeals, but merely as a means to gain power, after which the ideology is ignored or arbitrarily changed to serve the leader's personal objectives... Decisions of these leaders reflect a greater concern for self-glorification and maintaining power than for the welfare of followers (Yukl, 2006, p. 272)

This review describes the applicability of leadership theory as developed in the West while some applicability to other cultures has been found, they are, largely, inadequate to explain or predict leadership across cultures. One alternative to trying to ascertain the boundaries associated with these theories is to examine leadership theories that are indigenous to non-Western cultures.

\section{Leadership from Non-Western Perspective}

What types of leadership theories have been advanced in non-Western countries? There are some long-term leadership research programs exist outside the West as the ideology of Confucian Tianxia worldview, but some non-Western scholars have advanced particularistic views of leadership cognized of their indigenous cultures (House, et. al., 2004). There are two non - Western theorists stand out in importance and have been studied in some cross-cultural contexts (Dorfman, 1996). The first is Misumi's research in Japan over the past 40 years and the second is Sinha's research in India.

According to House, et. al., (2004), Misumi's performance-maintenance (PM) theory of leadership (1985) identifies four types of leaders based on the extent to which they focus on two basic leadership functions labeled Performance and Maintenance. The Performance (P) function reflects two aspects: a leader's planning, guiding, and developing work procedures; and pressure on subordinates to work hard and get the work done. The Maintenance (M) function reflects the leader's promoting of group stability and social processes.

These central leadership functions are conceptually similar to the "task-oriented" and "support-oriented" or "relationship-oriented" leadership function found in
Western theories of leadership.

According to Smith (1997), Misumi's results suggest that for effective leadership in Japan, supervisors must emphasize Performance-oriented (P) and Maintenance-oriented (M) factors together, and the specific behaviors associated with each function will vary according to context. Misumi's PM leadership instrument was adapted for use in China, but researcher found it necessary to add an additional leadership factor, labeled " $\mathrm{C}$ " for character and morals, to adequately characterize Chinese leadership (Ling \& Fang, 2003).

Similar to Misumi's research in Japan, early efforts to study leadership in India were influenced by conceptual links to Western social scientists. Sinha (1980, 1984) developed a Nurturant-task oriented model (NT) that incorporated a combination of leadership styles. The model suggests that an ideal leader in India is both nurturant and task-oriented. According to the theory, a nurturant-task-oriented (NT) leader needs to show affection, care for subordinates and commit toward their growth. However, the leader's nurturance is contingent on the subordinate's task accomplishment - the leader becomes a benevolent source of support provided that the subordinate respects and obey the supervisor, works hard and is highly productive. At this point in the relationship, however, the leader can encourage the subordinate to be more independent to actively participate with the leader in decision making. Still, this relationship is very much like the Japanese management-familyism system (Whitehill \& Takezawa, 1968).

As a final consideration of non-Western conceptualization of leadership is in countries very different from the West as in the Arabic world of the Middle East. In Arabic, the word of leadership is al kiyada, which refers to officers in the military or high-ranking members of the government (Hagan, 1995). Modern Arab management practices have been influenced by Islamic religion, tribal and family traditions, the legacy of colonial bureaucracies, and contact with Western nations (Ali, 1990).

Scandura and colleagues (1999) found striking differences in effective leadership styles between U.S. managerial sample and a sample of manager from the Middle East (Jordan and Saudi Arabia). Whereas the people-oriented style was related to job satisfaction and leader effectiveness for the U.S. sample, the task-oriented style was not. Opposite results were found for the Middle East sample. Strong and decisive leadership is expected from an Arab person. Scandura and Dorfman (Scandura and Dorfman, in press) also discuss culture and charismatic leadership that particularly relate to the Middle East.

According to Acharya and Buzan (2010) propose three different sources within the Islamic world for framing the debates about international relations or how Islam is supposed to interact with others. First, a primary foundation for the classical understanding of leadership 
concept in Islam is based on the original sources of the Qur'an, the Hadith (Sayings of the Prophet), the Sunnah (the conduct of the Prophet) or ijtihad (interpretation), which could call classical ideas, traditions and thinking contributing to "localist exceptionalism".

A second debate, Acharya and Buzan (2010) call "rebellions against prevailing orthodoxies", and was led by national leaders, is examined within the framework of imitation/reaction that came about as a result of encounters with the West.

A third recreation/reconciliation attempt is presented around the Islamization of knowledge movement as the reconceptualization of social sciences, and international relations by extension.

A consideration of non -Western conceptualization of leadership is partly similar from the theory of managing in Chinese history, in which Confucius's view occupies a central position. Brett (1997) observed that the Confucian influence extended to those Eastern societies located within the China cultural orbit namely Korea, Japan, Hong Kong, Taiwan and Singapore and out of overseas Chinese communities everywhere. At the heart of Confucianism is humanism; the basic principles of humanity (Goldin, 2011, Rosemont Jr, 2006, Tu, 1998a), in which moral cultivation and living in a moral way is the life-long endeavour of human beings. These principles are built on the belief that human beings are teachable, improvable and perfectible through personal and communal endeavour especially self-cultivation and self-creation. The principles are believed to be "the root of social relationships, the foundation of the stability, peace and prosperity of the state, the family and individuals" (Tu, 1998a). Rather than focus on the Western idea of management, which emphasizes competition among individuals and a "star" system, the Confucian approach centers around harmony, conformity, and community.

In sum, sources of non-Western conceptualization of leadership in countries as China, Arab-Persian, Islamic world, including classical traditions and thinking of religious, political and military figures (e.g. Confucian's worldview, the Qur'an, the Sunnah (traditions), the Hadith (Sayings of the Prophet) and the Sharia (Islamic law), Misumi's performance-maintenance (PM) in Japan and nurturant-task oriented model of Sinha in India not only employed by Western scholars in their study of Asia but also as used by local scholars in studying their home country, contribute to the marginalization of local scholarship and the country itself.

\section{Discourse between Leadership Theories from Western Perspective and Non-Western Perspective}

Commonalities in effective leadership process between theories of Western-dominated leadership and
non-Western conceptualizations of leadership which researchers have shown that first, the nature of both of Western and non-Western leadership theories predict based on the essence of power. Power in its various forms (coercive, legitimate, reward and expert, bureaucratic and charismatic power) is present to some degree in any leader-follower relationship (French \& Raven, 1959; Janda, 1972 \& Bums, 1978). Second, situational factors play a critical role in determining when a particular leader behavior is most effective. The actual leader behaviors are directive, supportive, participative, contingent reward and punishment, and charismatic behaviors. Each of these has shown potential importance in cross-cultural research (Al-Gattan, 1985; Bass \& Yokochi, 1991; Bond \& Hwang, 1986; Dorfman, 1996; House, 1991; Misumi \& Peterson, 1985b; Sinha, 1980). Third, the universality of leader supportiveness considers the specific content of two Western and non-Western leadership theories. Supportive leaders show concern for followers, considerate and are available to listen to followers' problems such as in leadership from non-Western perspective of Misumi's performance-maintenance (PM) theory of leadership, these central leadership functions are conceptually similar to the "task-oriented" and "support-oriented" or "relationship-oriented" leadership function found in Western theories of leadership. A leader who demonstrates supportive kindness and concern for followers is clearly valued and impactful in all the cultures (Bennett, 1977; Misumi \& Peterson, 1985a; Yukl, 1994).

The first difference in the leadership process between theories of Western-dominated leadership and non-Western conceptualizations of leadership shows that the major component of the Western leadership theories is that they separate individual and professional life. The key attributes of leadership are experience, expertise and decision-making skills needed to accomplish tasks, achieve goals and ensure self- interest. The second, Western researchers indicate a belief that leaders do indeed make a difference in perception of Western-dominated leadership. Typical of an individualist culture will distinguish leaders from followers such as intelligence, self-confidence, determination, integrity and sociability to discover different traits for leadership success. In other words, the ability of individuals with effective leadership influences organization members toward the accomplishment of goals (Yukl, 1994b).

The third, Western-dominated leadership theories are designed to predict subordinates' motivation, satisfaction, and performance. The leaders motivate followers to pursue goals that transcend their immediate self- interest. From this perspective, scholars identified person-oriented, task-oriented and individual prominence behaviors as related to leadership effectiveness (House, 1971). The fourth, the leader behaviors have been widely researched in the American or European, these specific behaviors seem as being task or relationship-oriented by followers 
differ in ways that are consistent with the cultural setting. Leader behavior, which is consistent with what followers expect, will be more likely to result in an individual being perceived as a leader and, therefore, make him/her more effective. These behaviors are emphasized in the situational approach, they indicate that leadership effectiveness is carried out when leaders pick up cues in the environment and adopt their policies, behaviors and actions accordingly.

The fifth, the leadership in sources of the non-Western concept includes classical traditions and thinking of religious, military, political and military figures. Two theories stand out in importance and have been studied in some cross-cultural contexts, they consist of Misumi's view in performance-maintenance (PM) in Japan and nurturant-task oriented model of Sinha in India. And in the Arab- Islamic world, classical jurisprudence/scriptures/ tradition, modernist yearning, revivalist impulse and syncretism reconciliation between tradition and modernity are presented as possible sources of non-Western (Acharya \& Buzan, 2010). China's case is interesting, the Confucian Tianxia worldview is an inward-looking perspective emphasizing harmony, in contrast to the West's extroversive outlook is emphasizing competition in individuals. The sixth, non-Western leadership characteristics are seeking inspiration for subordinates by using persuasion rather than coercion, promoting equality, simple living and harmony with nature and others. Collectivist culture and power distance orientation are the two of the most prominent contextual factors of leadership in Asia (Chen \& Lee, 2008; Park and Koo, 2018).

To be sure, it is difficult to take a uniform view between sources of leadership from Non- Western Perspective and Western-dominated leadership, many scholars have highlighted varying approaches to leadership across societal cultures. Some similarities notwithstanding, many of the values deemed essential for leadership effectiveness is at variance with those found in many different countries. The Global Leadership and Organizational Behavior Effectiveness (GLOBE) program which undertook a cross-cultural longitudinal and multi-method research project in 62 countries investigated the impact of culture on leadership effectiveness. Using nine cultural dimensions (uncertainty avoidance, power distance, institutional collectivism, in-group collectivism, gender egalitarianism, assertiveness, future orientation, performance orientation and humane orientation), the GLOBE researchers divided the 62 countries into 10 clusters each unique in its own way.

The GLOBE study shows the linkages between culture and leadership providing evidence that leadership is different across cultures in various ways. The GLOBE research identifies cultural values influencing leadership practices. Cultural values are reflected into two distinct kinds of cultural manifestations: (a) the commonality (agreement) among members of collectives with respect to the psychological attributes specified above; (b) the commonality of observed and reported practices of entities such as families, schools, work organizations, economic and legal systems, and political institutions. Additionally, the GLOBE project identifies leadership patterns within cultures facilitating cross-cultural comparisons.

\section{The GLOBE Research Program and Cross-Cultural Leadership Perspectives}

\subsection{The GLOBE Research Program}

The Global Leadership and Organization Behavior Effectiveness Research Program (GLOBE) research could be called the Manhattan Project of the study of the relationship of culture to conceptions of leadership. One hundred and seventy investigators from 62 cultures worked on this project. Twenty of them participated in writing this project. They tested 27 hypotheses that linked culture to interesting outcomes, with data from 17,300 managers in 951 organizations. They measured the variables with cultural sensitivity, developing instruments in consultation with members of the relevant cultures. By using focus groups, and by heavy dependence on the previous literature, the investigators developed instruments that tapped local meanings that were appropriate for each level of the data and also had equivalence across cultures.

The major purpose of Project GLOBE is to increase available knowledge that relevant to cross-cultural interactions and there is wide variation in the values and practices relevant to the nine core dimensions of cultures and wide variation in perceptions of effective and ineffective leader behaviors.

\subsection{Cross-Cultural Leadership Perspectives}

Given the increasing globalization of industrial organizations and the growing interdependencies among nations, the need for a better understanding of cultural influences on leadership and organizational practices is necessary. Cross-cultural understanding of leadership and organization will help us test our knowledge in other countries, identify boundary conditions and identify potentially universal aspects of leadership. The results of the GLOBE research program fill a substantial knowledge gap concerning the cross-cultural forces relevant to effective leadership, effective organizational practices, national prosperity, and the physical and psychological welfare of members of cultures. House, et.al., (2004) describe the nine attributes of the core GLOBE cultural dimensions as below:

(1) Uncertainty Avoidance: members of an organization or society strive to avoid uncertainly by relying on 
established social norms, rituals, and bureaucratic practices. People in uncertainty avoidance cultures actively seek to decrease the probability of unpredictable future events that could affect the operation of an organization or society.

(2) Power Distance: the degree to which members of an organization or society expect and agree that power should be stratified and concentrated at higher levels of an organization or government.

(3) Collectivism I, Institutional Collectivism: the degree to which organizational and societal institutional practices encourage and reward collective distribution of resources and collective action.

(4) Collectivism II, In Group Collectivism: the degree to which individual express pride, loyalty, and cohesiveness in their organizations or families.

(5) Gender Egalitarianism: the degree to which an organization or a society minimizes gender role differences while promoting gender equality.

(6) Assertiveness: the degree to which individuals in organizations or societies are assertive, confrontational, and aggressive in social relationships.

(7) Future Orientation: the degree to which individuals in organizations or societies engage in future-oriented behaviors such as planning, investing in the future, and delaying individual or collective gratification.

(8) Performance Orientation: the degree to which an organization or society encourages and rewards group members for performance improvement and excellence.

(9) Humane Orientation: the degree to which individuals in organizations or societies encourage and reward individuals for being fair, altruistic, friendly, generous, caring and kind to others.

\subsection{Leader Behavior and Attributes in the GLOBE Research Program}

A major question addressed by GLOBE is the extent to which specific leader characteristics and actions are universally endorsed as contributing to effective leadership, and the extent to which these qualities and actions are linked to cultural characteristics. The Globe research identified six global leader behaviors influenced on societal cultural forces. These global leader behaviors (leadership dimensions) are briefly defined as follows:

\section{- Charismatic/ Value-Based Leadership}

A broadly defined leadership dimension that reflects an ability to inspire, to motivate, and to expect high performance outcomes from others based on firmly held core values. The GLOBE Charismatic/ Value-Based leadership dimension includes six leadership subscales labeled (1) visionary, (2) inspirational, (3) self-sacrifice, (4) integrity, (5) decisive, and (6) performance oriented.

\section{- $\quad$ Team-Oriented Leadership}

A leadership dimension that emphasized effective team building and implementation of a common purpose or goal among team members. This leadership dimension includes five subscales labeled (1) collaborative team orientation, (2) team integrator, (3) diplomatic, (4) malevolent (reverse scored), and (5) administratively competent.

\section{- $\quad$ Participative Leadership}

A leadership dimension that reflects the degree to which managers involve others in making and implementing decisions. The Globe addresses leadership dimension includes two subscales labeled (1) non-participative and (2) autocratic.

\section{- Humane-Oriented Leadership}

A leadership dimension that reflects supportive and considerate leadership but also includes compassion and generosity. This leadership dimension includes two subscales labeled (1) modesty and (2) humane orientation.

\section{- Autonomous Leadership}

A newly defined leadership dimension that refers to independent and individualistic leadership attributes. This dimension is measured by a single subscale labeled autonomous leadership, consisting of individualistic, independence, autonomous, and unique attributes.

\section{- $\quad$ Self-Protective Leadership}

From a Western perspective, this newly defined leadership behavior focuses on ensuring the safety and security of the individual and group through status enhancement and face-saving. This leadership dimension includes five subscales labeled (1) self-centered, (2) status-conscious, (3) conflict inducer, (4) face-saver and (5) procedural.

A more systematic approach to cross-cultural research on leadership was taken in the GLOBE project. The research on cultural values finds important differences that are relevant for beliefs about effective leadership and the actual behavior of leaders. Knowledge of cultural differences is certainly helpful for leaders. Furthermore, cultural heterogeneity among countries also implies challenges and adjustments in managerial approaches. According to Northouse (2010), global leaders need to develop five cross-cultural competencies: First, leaders need to understand socio-economic, political and cultural environments worldwide. Second, they need to learn the perspectives, trends, and technologies of many other cultures. Third, they need to be able to work simultaneously with people from many cultures. Fourth, leaders must be able to adapt to living and communicating in other cultures. Fifth, they need to learn to relate to people from other cultures from a position of equality rather than cultural superiority. 
The core of global leadership is the ability to influence people who are not like the leader and come from different cultural backgrounds. To succeed, global leaders need to have a global mindset tolerate high levels of uncertainty, and show cultural adaptability and flexibility.

\section{Conclusions}

The leadership literature, as sketched above, is based upon assumptions reflecting Western and Non - Western culture. Most of the prevalent leadership theories and the empirical evidence supporting them are distinctly American or European in character. They emphasize values that are individualistic, hedonistic and rational as against collectivist, altruistic and religion. Values that are emphasized in other cultures, particularly those derived from religion, are ignored or are given scant recognition. The major component of the Western and Non - Western leadership theories is that they separate individual and professional life. The key attributes of leadership are experience, expertise and decision-making skills needed to accomplish tasks, achieve goals and ensure self - interest. Not much attention is paid to values and ethics for formatting of the leader's characteristics which is considered by many to be at the root of contemporary leadership crisis. A particularly important issue in contemporary cross-cultural research is constructed equivalence.

In the GLOBE project, the impact of culture on attributes perceived to be effective for organizational success was studied in 62 different national cultures (House et al., 2004). There are six global leader behaviors in the findings of the GLOBE project. These dimensions indicate characteristics, skill and abilities culturally perceived to contribute to outstanding leadership. The leadership profiles identified in the GLOBE studies is useful in a very practice sense. The societal and organizational values help to outline culture-specific boundaries of acceptable, effective leader behaviors and practices. Leaders who are aware of a culture's values and practices can be made conscious, educated decisions regarding their leadership practices and likely effects on the day-to-day operations and crisis management within an organization. Acknowledgment and explanation from a leader to his followers is that a customary cultural practice will be breached and why can help avoid or diminish problems and complications.

\section{Appendix 1 - Comparison of Leader's Trait for the New Leadership Models}

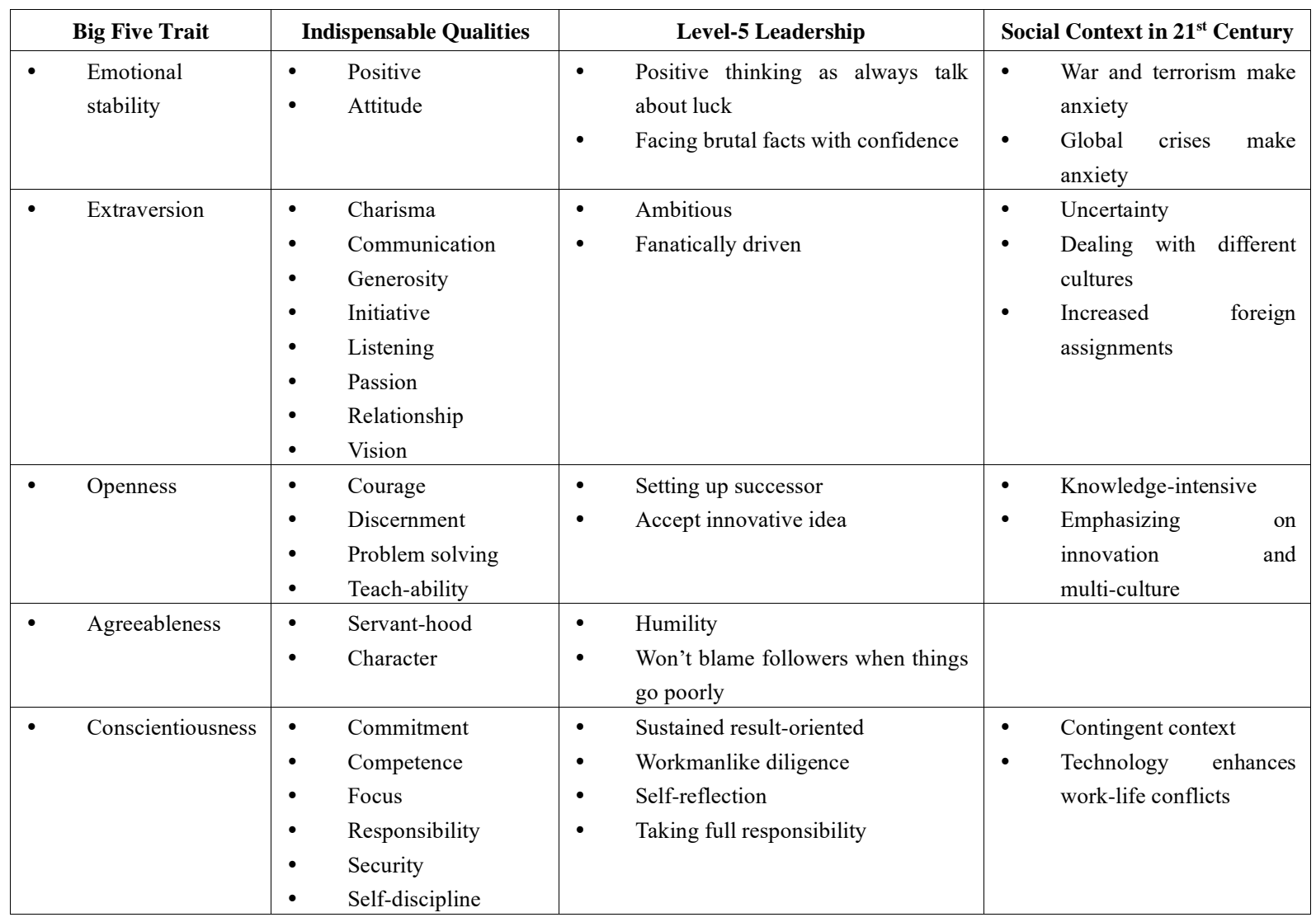

Source: Adapted from Hugo, 2009, p. 5 


\section{Appendix 2 - A Summary of Specific Leader Behaviors in a Task-oriented, Relationship-oriented, Change-oriented Leadership Style}

\begin{tabular}{|c|c|c|}
\hline Task-Oriented Behaviors & Relations-Oriented Behaviors & Change-Oriented Behaviors \\
\hline $\begin{array}{l}\text { - Organize work activities to } \\
\text { improve efficiency. } \\
\text { - Plan short-term operations. } \\
\text { - Assign work to groups or } \\
\text { individuals. } \\
\text { Clarify what results are } \\
\text { expected for a task. } \\
\text { - Set specific goals and } \\
\text { standards for task } \\
\text { performance. } \\
\text { Explain rules, policies, and } \\
\text { standard operating procedures. } \\
\text { Direct and coordinate work } \\
\text { activities. } \\
\text { Monitor operations and } \\
\text { performance. } \\
\text { Resolve immediate problems } \\
\text { that would disrupt the work }\end{array}$ & $\begin{array}{l}\text { - Provide support and encouragement to } \\
\text { - } \quad \text { Express confidence that a person or } \\
\text { group can perform a difficult task. } \\
\text { - Socialize with people to build } \\
\text { relationships. } \\
\text { Recognize contributions and } \\
\text { accomplishments. } \\
\text { Provide coaching and mentoring when } \\
\text { appropriate. } \\
\text { Consult with people on decisions } \\
\text { affecting them. } \\
\text { Allow people to determine the best } \\
\text { way to do a task. } \\
\text { Keep people informed about actions } \\
\text { affecting them. } \\
\text { Help resolve conflicts in a constructive } \\
\text { way. } \\
\text { Use symbols, ceremonies, rituals, and } \\
\text { stories to build team identity. } \\
\text { Recruit competent new members for } \\
\text { the team or organization. }\end{array}$ & $\begin{array}{l}\text { - Monitor the external environment to } \\
\text { detect threats and opportunities. } \\
\text { Interpret events to explain the urgent } \\
\text { need for change. } \\
\text { - Study competitors and outsiders to get } \\
\text { ideas for improvements. } \\
\text { Envision exciting new possibilities for } \\
\text { the organization. } \\
\text { Encourage people to view problems or } \\
\text { - opportunities in a different way. } \\
\text { Develop innovative new strategies } \\
\text { linked to core competencies. } \\
\text { Encourage and facilitate innovation and } \\
\text { - entrepreneurship in the organization. } \\
\text { Encourage and facilitate collective } \\
\text { learning in the team or organization. } \\
\text { Experiment with new approaches for } \\
\text { achieving objectives. } \\
\text { Make symbolic changes that are } \\
\text { consistent with a new vision or strategy. } \\
\text { Encourage and facilit ate efforts to } \\
\text { implement major change. } \\
\text { Announce and celebrate progress in } \\
\text { implementing change. } \\
\text { Influence outsiders to support change } \\
\text { and negotiate agreements with them. }\end{array}$ \\
\hline
\end{tabular}

Source: Adapted Yukl (2006), p. 70

\section{Appendix 3 - Key Attributes of Transformational Leader to Meet Changes in the World}

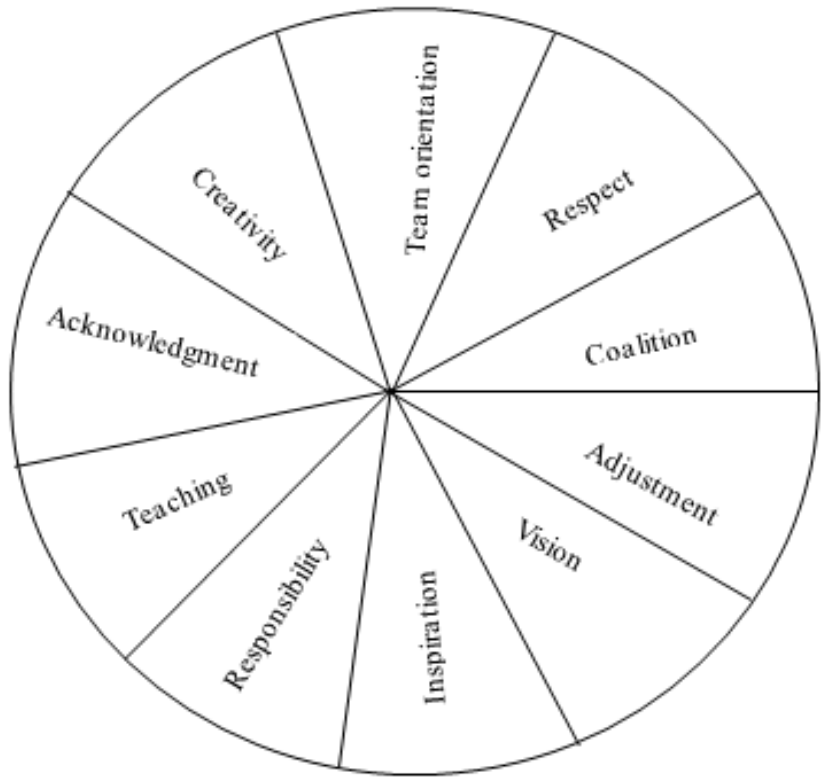

Source: Adapted from Nikezic, etc., (2013) 


\section{Appendix 4 - List of the Attributes of Positive Charismatic Leader}

\begin{tabular}{|c|c|}
\hline Features of Positive Charismatic Leader & Ability of Positive Charismatic Leader \\
\hline Confidence & Charismatic leaders deeply believe in their own thinking and ability. \\
\hline - Vision & $\begin{array}{l}\text { Charismatic leaders have an idealized goal that takes precedence over the present. The } \\
\text { difference between the desired and current state of the attitude of the followers of the visionary } \\
\text { qualities of leaders. }\end{array}$ \\
\hline - $\quad$ Ability to express a vision & $\begin{array}{l}\text { Charismatic leaders are able to successfully explain and present a vision. Ability to express the } \\
\text { vision shows the ability of leaders to understand the needs of followers and to motivate them. }\end{array}$ \\
\hline Strong belief in a vision & Charismatic leaders are willing to risk, sacrifice and commitment to achieve the vision \\
\hline Unusual behavior & Their behavior is not conventional, but unusual and it is outside the existing rules and norms. \\
\hline - They appear as change agents & $\begin{array}{l}\text { Charismatic leaders are the bearers of radical changes and requirements. They do not advocate } \\
\text { of waiting and keeping the status quo. }\end{array}$ \\
\hline - Sense of the environment & $\begin{array}{l}\text { Charismatic leaders realistically assess the impact and limitations of environment, as well as } \\
\text { events that can cause certain changes. }\end{array}$ \\
\hline
\end{tabular}

Source: Adapted from Nikezic, etc., p 184

\section{Appendix 5 - Some Negative Consequences of Charismatic Leaders}

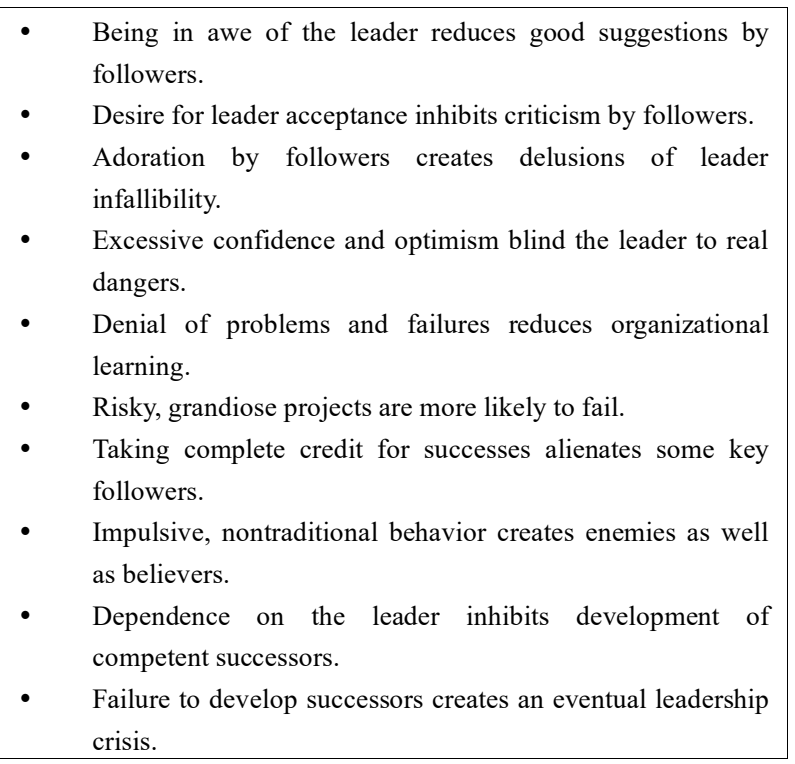

Source: Adapted from Yukl, 2006, p. 273

\section{REFERENCES}

[1] Acharya, A., Buzan, B. (2010). Non-Western International Relations Theory. Perspectives on and beyond Asia. London and New York: Routledge

[2] Al-Gattan, A.R.A. (1985). Test of the path-goal theory of leadership in the multi-national domain. Group and Organization Studies, 10(4), 429-445.

[3] Ali, A.J. (1990). Management theory in a transitional society: The Arab's experience. International Studies of Management and Organization, 20 (7), 7-35.

[4] Bartlett, C., Ghoshal, S. (1988), "Organizing for worldwide effectiveness: The transnational solution". California
Management Review, 31(1) 54-74.

[5] Bartlett, C.A., Ghoshal, S., Birkinshaw, J. (2004) Transnational management: Text, cases and readings in crossborder management. Boston: McGrawHill-Irwin.

[6] Bass, B.M., \& Yokochi, N. (1991). Charisma among senior executives and the special case of Japanese CEOs. Consulting Psychology Bulletin, 1(Winter/Spring), 31-38.

[7] Bass, B.M. (1990). Bass and Stogdil's handbook of leadership: theory, research and managerial application. New York: Free Press.

[8] Bass, B.M. (1991). Is there universality in the full range model of leadership? Paper presented at the national academy of management annual meeting, Miami.

[9] Bass, B.M. (1997). Does the transactional - transformational leadership paradigm transcend organizational and national boundaries? American Psychologist, 52(2)130-139.

[10] Bass, B. M., \& Avolio, B. J. (2004). Multifactor leadership questionnaire: Manual and sampler set (3rd ed.). CA: Mind Garden, Inc.

[11] Bennett, M. (1977). Testing management theories cross-culturally. Journal of Applied Psychology, $62,578-581$

[12] Blunt, P. (1991). Organizational culture and development. International Journal of Human Resource Management, 2(1)65.

[13] Bond, M., \& Hwang, K. (1986). The social psychology of Chinese people. In M.H. Bond (Ed.). The psychology of the Chinese people (pp. 213-237). Hong Kong: Oxford University Press.

[14] Bono, J. E., \& Judge, T. A. (2004). Personality and transformational and transactional leadership: A meta-analysis. Journal of Applied Psychology, 89 (5), 901-910.

[15] Bums, J. M. (1978). Leadership. New York: Harper and Row.

[16] Charbonneau, D., Barling, J., \& Kelloway, E. K. (2001). Transformational leadership and sports performance: The mediating role of intrinsic motivation. Journal of Applied Social Psychology, 31 (7), 1521-1534. 
[17] Chen C.C., Lee Y.T. (2008). Leadership and management in China: Philosophies, theories and practices. Cambridge: Cambridge University Press.

[18] Collins, J. (2001). Good to Great: Why Some Companies Make the Leap... and Others Don't. New York: Harper Collins.

[19] Conger, J. A., \& Kanungo, R. (1987). Toward a behavioral theory of charismatic leadership in organizational settings. Academy of Management Review, 12, 637-647.

[20] Conger, J. A., \& Kanungo, R. (1998). Charismatic leadership in organizations. Thousand Oaks, CA: Sage Publications.

[21] Dorfman, P.W. (1996). International and cross-cultural leadership, in J Punnitt and O Shenkar (eds), Handbook for International Management Research, Cambridge, MA: Blackwell.

[22] Echavarria, N.U., Davis, D.D. (1994). A test of Bass's model of transformational and transactional leadership in the Dominican Republic, paper presented at the 23rd international congress of applied psychology, Madrid.

[23] French, J.R.P. Jr., Raven, B. (1959). The bases of social power: For types of power and authority. In Darwin Cartwright ed., Studies in Social Power. Ann Arbor: University of Michigan; Gerth, H.A. and C. Wright Mills eds. 1958. From Max Weber: Essays in Sociology. New York: Oxford University Press.

[24] Gill,R., (2006). Theory and Practice of Leadership. CA: Sage Publications.

[25] Gilbert, W.F. (1994). Leadership and the Culture of Trust. Praeger, Westport: Greenwood.

[26] Goldin, P. R. (2011). Confucianism. Berkeley: University of California Press.

[27] Graumann, C.F., \& Moscovici, S. (1986). Changing conceptions of leadership, New York: Springer-Veriag.

[28] Greer, B. M. (2013). 21st Century Leadership: Harnessing Innovation, Accelerating Business Success. Indiana: iUnivers Publishing.

[29] Hagan, C.M. (1995). Comparative management: Africa, the Middle East, and India. (Working paper) Boca Raton, FL: Florida Atlantic University.

[30] Hartog, D.N., Muijen, V.J.J., Koopam, P.L. (1994). Transactional versus transformational leadership: An analysis of the MLQ in the Netherlands, paper presented at the 23rd international congress of applied psychology, Madrid.

[31] House, R.J. (1971). A path-goal theory of leader effectiveness. Administrative Science Quarterly, 16, 321-338.

[32] House, R.J. (1991). Charismatic leadership across cultures. Paper presented at the Academy of Management Annual Meeting, Miami, FL.

[33] House, R.J., Mitchell, R.R. (1974). Path- goal Theory of Leadership, J. Contemporary Business, 3(2) 81-97.

[34] House, R. J., Wright, N. S., \& Aditya, R. N. (1997).
Cross-cultural research on organizational leadership: A critical analysis and a proposed theory. In P. C. Earley \& M. Erez (Eds.), New Perspectives in International Industrial Organizational Psychology (pp. 535-625). San Francisco: New Lexington,

[35] House, R., Javidan, M., \& Dorfman, P. (2001). Project GLOBE: An Introduction. Applied Psychology: An International Review, 50(4), 489-505.

[36] House, R.J., Hanges, P.J., Javidan, M., Dorfman, P.W., \& Gupta, V. (2004). Culture, leadership, and organizations: The GLOBE study of 62 societies. Thousand Oaks,CA: Sage.

[37] Howell. J.P., Dorfman, P.W. (1988). A comparative study of leadership and its substitutes in a mixed cultural work setting. Paper presented at the Western Academy of Management review, Big Sky, Montana.

[38] Howell, J.P., Dorfman, P.W., Hibino, S., Lee, J.K., Tate, U. (1994). Leadership in Western and Asian countries: Commonalities and differences in effective leadership processes and substitutes across cultures. Center for Business Research, New Mexico State University.

[39] Hugo, T. (2009). Leadership model in 21st century. From https://ssrn.com/abstract=2890181 or http://dx.doi.org/10.2 139/ssrn.2890181

[40] House, R.J. (1977). A 1976 theory of charismatic leadership. In J.G. Hunt \& L.L., Larsen (Eds.), Leadership: The ctting edge. Carbondate (pp. 100-125). IL: Southern Illinois University Press.

[41] Jacobsen, C., \& House, R. J. (2001). Dynamics of charismatic leadership: A process theory, simulation model, and tests. Leadership Quarterly, 12, 75-112.

[42] Janda, K.F. (1972). Towards the Explication of the Concept of Leadership in terms of the Concept of Power. In Paige, Glenn ed., Political Leadership. New York: Free Press.

[43] Koh, W.L. (1990). An empirical validation of the theory of transformational leadership in secondary schools in Singapore. Ph.D dissertation, University of Oregon. 52-55.

[44] Ling, W.Q., \& Fang, L. (2003). The Chinese leadership theory, In W.H.Mobley \& P.W. Dorman (Eds.), Advances in global leadership, 3, 183-204.

[45] Marsh, N.R. (1978). Constructs of power and authority and their attitudinal and behavioral outcomes: A comparative study of European and Polynesian first-line supervisors. Unpublished $\mathrm{PhD}$ thesis, University of Bath, Bath

[46] Maxwell, J. C. (1999). The 21 indispensable qualities of a leader. Nashville, TN: Thomas Nelson.

[47] Misumi, J., \& Peterson, M.F. (1985a). The behavioral science of leadership: An interdisciplinary Japanese research program. Ann Arbor, MI: University of Michigan Press.

[48] Nikezić, S., Marković, S., \& Bataveljić, D. (2013). Transformational and charismatic leadership - Full range leadership model: Paradigm for change. Technics Technologies Education Management (TTEM), 8(2), 713-722.

[49] Nikezić, S., Doljanica, S., Bataveljić, D. (2013). Charismatic 
and transformational leadership: Approches for effecting change. Technics Technologies Education Management (TTEM), 3(2), 179-187.

[50] Northouse, P.G. (2010). Leadership: Theory and Practice, 5tyh Ed. Thousand Oaks, CA: Sage Publications.

[51] Park H., Koo Ch. (2018). Foundation of leadership in Asia: Leader characteristics and leadership styles review and research agenda, Asia Pacific Journal of Management, $35(3), 697-718$

[52] Peterson, M. F., \& Hunt, J. G. (1997). International perspectives on international leadership. Leadership Quarterly, 8(3), 203-229.

[53] Robbins, S. P. \& Judge, T. A. (2009). Organizational behaviour (13th ed.). New Jersey: Pearson International, Inc.

[54] Rosemont Jr, H. (2006). Two loci of authority: Autonomous individuals and related persons. In P. D. Hershock \& R. T. Ames (Eds), Confucian cultures of authority (pp. 1-20). Albany: State University of New York Press.

[55] Scandura, T.A., Von Glinow, M.A., \& Lowe, K.B. (1999). When East meets West: Leadership "best practices" in the United States and the Middle East. Advances in global leadership, 1, 235-248.

[56] Shamir, B., Zakay, E., \& Popper, M. (1998). Correlates of charismatic leader behavior in military units: Subordinates' attitudes, unit characteristics, and superiors' appraisals of leader performance. Academy of Management Journal, 41, 387-409.

[57] Sinha, J.B.P. (1980). The nurturant task leader. New Delhi: Concept.

[58] Sinha, J.B.P. (1984). A model of effective leadership styles in India. International studies of management and organization, 14(3), 86-98.

[59] Sinha, J.B.P. (1995). The cultural context of leadership and power. Sage Publication: New Delhi.

[60] Smith, P.P. (1997). Cross-cultural leadership: A path to the goal? In P.C. Early \& M.Erez (Eds.), New perspectives on international industrial/organizational psychology (626-639). San Francisco: New Lexington Press.

[61] Tannenbaum, A.S. (1980). Handbook of cross-cultural psychology: Organizational psychology. Boston: Allyn and Bacon.

[62] Timothy, A.J., Erin, F.W., Charlice, H., \& Beth L. (2006). Charismatic and tranformational leadership: A review and an agenda for future research. zeitschrift für Arveits-u. Organisationspsychologie, 50(4), 203-214.

[63] Tu, W. M. (1998a). Confucius and Confucianism. In W. H. Stole \& G. A. Devos (Eds.), Confucianism and the family (pp. 3-36). New York: State University of New York Press.

[64] Weber, M. (1947). The theory of social and economic organization. New York: Free Press.

[65] Whitehill, A.M., \& Takezawa, S. (1968). The other worker. Honolulu: East-West Center Press.

[66] Yukl, G. (1994). Leadership in organizations, 3rd ed.
Englewood Cliffs, NJ: Prentice-Hall.

[67] Yukl, G.A. (2002). Leadership in organizations (5th ed). Upper Saddle Rivers, $\mathrm{Nj}$ : Prenice Hall.

[68] Yukl, G., (2006). Leadership in Organization (8th Ed.). Pretice Hall: Pearson Education, Inc. 